\title{
Menarcheal Age and Nutritional Status of Secondary School Adolescent Girls in Nnewi, South-East Nigeria
}

\author{
Joseph Ifeanyi Brian-D Adinma ${ }^{{ }^{*}}$, Richard Obinwanne Egeonu, \\ Nneoma Dolores Adinma-Obiajulu' ${ }^{1}$ Ekene Agartha Emeka² \\ ${ }^{1}$ Department of Obstetrics and Gynaecology, Nnamdi Azikiwe University Teaching Hospital, Nnewi, Nigeria \\ ${ }^{2}$ Department of Family Medicine, Nnamdi Azikiwe University Teaching Hospital, Nnewi, Nigeria \\ Email: ^brianadinma@yahoo.com, ^br.adinma@unizik.edu.ng
}

How to cite this paper: Adinma, J.I.B., Egeonu, R.O., Adinma-Obijulu, N.D. and Emeka, E.A. (2021) Menarcheal Age and Nutritional Status of Secondary School Adolescent Girls in Nnewi, South-East Nigeria. Advances in Reproductive Sciences, 9, 139148.

https://doi.org/10.4236/arsci.2021.92014

Received: January 14, 2021

Accepted: May 22, 2021

Published: May 25, 2021

Copyright $\odot 2021$ by author(s) and Scientific Research Publishing Inc. This work is licensed under the Creative Commons Attribution International License (CC BY 4.0).

http://creativecommons.org/licenses/by/4.0/

\section{(c) (i) Open Access}

\begin{abstract}
Background: Menarche is an important indicator of pubertal development in adolescent girl. Age at menarche has declined over the years attributable to many factors. Objective: To determine the age at menarche of secondary school adolescent girls and its relationship with anthropometric values, nutritional status, social class of parents, and category of school. Subjects and Methods: Cross-sectional study of 311 secondary school adolescent girls (10 19 years) from two secondary schools (boarding school- Maria Regina secondary school Nnewi and Anglican Girls Secondary School Nnewi-day school) in Nnewi North LGA of Anambra State, Southeastern Nigeria, between May and June 2018. Semi-structured questionnaires were used to extract their data on sociodemographic characteristics and age at menarche. Height and weight were measured using WHO recommended methods. Body mass index (BMI) was determined using the Quetelet index $\left(\mathrm{kg} / \mathrm{m}^{2}\right)$. The relationship between menarche and anthropometric measurement was determined. Results: Of the 313 participants, $212(68.2 \%)$ were post menarcheal, while 99 (31.8\%) were pre-menarcheal. The mean age at menarche was $12.79 \pm 1.20$ years. Early menarcheal age was associated with significantly higher anthropometric values and BMI. Boarding-students had significantly lower menarcheal age (12.69 $\pm 1.26)$ compared to the day students $(12.86 \pm 1.15)$; students with parents of the high social class had lower menarcheal age (12.56 \pm 1.51$)$, compared to those with parents of low social class $(12.90 \pm 1.05)$. Conclusion: There was a significant relationship between age at menarche and the nutritional status of the participants. Students with parents of high social class and those in boarding houses had a relatively lower age at menarche. Adequate attention should be given to the nutrition of premenarcheal school girls and those of parents with low social class. Boarding school authorities should ensure measures to alleviate stress amongst boarding-school students.
\end{abstract}




\section{Keywords}

Adolescent, Nutritional Status, Menarche

\section{Introduction}

Menarche, the first menstrual period is a landmark indicator of puberty, and the age at which girls attain menarche has shown variation across the globe [1]. The average age at menarche has been on the decrease, and this is attributed to several factors such as nutritional status, genetic, environmental conditions, socioeconomic status, and education [2]. Notable among the above factors is the nutritional status. Girls with poor nutritional status have been shown to have delayed menarche compared to those that have good nutritional status [3]. The amount of body fat needed for menses to occur is about $17 \%$ of the total body weight at menarche [4]. It is believed that girls with good nutrition tend to achieve this minimum percentage of body fat, and hence, earlier menarcheal age.

The age of menarche varies globally. For instance, the age at menarche in England is 13.1 years while that in the Burundi tribe in Papua New Guinea is 18.8 years [5]. In Indonesia, menarcheal age is 13 years [6]. Carnelo et al., in a systematic review, reported age at menarche in a USA population to be 12 years [7]. In Nigeria, the average age at menarche varies from one geopolitical zone to another [8]-[13]. For example, In Port Harcourt, the average age at menarche has been reported by Okagua et al. to be $12.45 \pm 1.24 \mathrm{yrs}$ [8], while in Benin City it is 12.3 yrs [10]. However, Tunauet al. [12] reported a higher age at menarche of 15.26 yrs among school girls in Sokoto, Nigeria.

Nutrition plays a vital role in several aspects of the development of womenduring the adolescence, pre-pregnancy, pregnancy, and postpartum period, and has constituted a major policy thrust in several nations of the world, including Nigeria [14] [15] [16] [17]. Nutritional concern has also constituted the basis for several studies related to macro- and micro-nutrients and the need for their supplementation especially in pregnant women [18] [19] [20].

Reports have shown that girls who have higher BMI are likely to attain menarche earlier than their premenarcheal peers, indicating the relationship between nutritional status and menarche [11] [13] [21]. This study has been undertaken to determine the relationship between menarcheal age and anthropometric indices among secondary school adolescent girls in Nnewi, Southeastern Nigeria. It also elicits the relationship if any between the age at menarche and the social class of the parents of the students together with the pattern of their schooling system i.e. whether boarding or day students.

\section{Subjects and Methods}

This was a cross-sectional study, conducted among 311 secondary school ado- 
lescent girls (10 - 19 years) from two secondary schools (one boarding school and one day school) in Nnewi North LGA of Anambra State of south-eastern Nigeria between May and June 2018. Nnewi North LGA is one of the 21 local government areas of Anambra state. It is located in the southern senatorial zone of Anambra State, and comprises Nnewi urban town and the adjoin Ichi rural community. The city spans over $2789 \mathrm{~km}$ square [22] and is mainly inhabited by traders with few civil servants and artisans.

\section{Sample Size and Sampling Technique:}

The sample size will be determined as per standard method recommended by the WHO Expert Committee (1995) [23] for studies involving nutritional status. The sample will be calculated using a power calculation (Cole 1997) [24].

$$
n=\left[Z^{2} P(100-P)\right] / X^{2}
$$

where, $Z=Z$ value (example 1.96 for $95 \%$ confidence interval), $P=$ percentage adolescent girls assumed having poor nutritional status. $P$ will be taken to be 23\% since the National Demographic and Health Survey 2013 showed that 23\% of adolescent girls were undernourished, 100-P = Percentage of adolescent girls assumed to have good nutritional status. $X=$ Width of the Confidence interval or required precision level is taken to be $5 \%$.

$$
\begin{aligned}
n & =\left[Z^{2} P(100-P)\right] / X^{2} \\
& =\left[1.96^{2} \times 23(100-23)\right] / 5^{2} \\
& =(3.842 \times 23 \times 77) / 25 \\
& =6804.18 / 25 \\
& =272.16
\end{aligned}
$$

Add $10 \%$ of the number to take care of drop out $=28$

$$
272 \text { plus } 28=300
$$

Three hundred adolescent girls were recruited for the study. One fifty (150 participants) from a Day school and the other from a Boarding school. List of schools from the study area was obtained from the Anambra State Ministry of Education. A multistage stratified random sampling technique was employed. The schools were stratified into boarding and day schools, following which one school was selected from each category. Permission for the study was obtained from both the Education Ministry and from the authorities of the participating schools. Ethical approval was obtained from the ethics committee of Nnamdi Azikiwe University Teaching Hospital (NAUTH/CS/66/VOL.10/226/2017/140) and appropriate participatory consent was elicited and obtained from the participants (assent), and in some cases, together with their parents. A pre-validated questionnaire designed by the researchers (containing 13 stems with some subdivisions) was used to elicit information with respect to the socio-demographic characteristics of the students, parents' occupation/educational qualification, age at menarche, duration of flow, associated dysmenorrhoea, height, weight and nutritional status (see the attached). Students with chronic illnesses were ex- 
cluded from the study. The height of the participants was measured using a stadiometer with a sliding headpiece while their weight was measured using a portable weighing scale (Scale 2000, Portable Physician's Scale). The BMI, which measured the nutritional status, was calculated as weight in kilogramme $(\mathrm{kg}) \mathrm{di}$ vided by the squared height in meters $\left(\mathrm{m}^{2}\right)$. BMI value below $18.5 \mathrm{~kg} / \mathrm{m}^{2}$ indicates undernutrition; between 18.5 and $24.9 \mathrm{~kg} / \mathrm{m}^{2}$ indicates normal nutrition; between 25.0 - $29.9 \mathrm{~kg} / \mathrm{m}^{2}$ indicates over nutrition; and from 30.0 to $34.9 \mathrm{~kg} / \mathrm{m}^{2}$ indicates obesity [25]. Data analysis was performed using SPSS software version 23 (IBM Corporation, Atlanta, GA, USA). Descriptive statistics were determined where applicable such as the mean menarcheal age and mean nutrient intake as well as inferential statistics like the f-test. P-values of less than 0.05 at $95 \%$ confidence interval, was statistically significant.

\section{Results}

Of the 311 students studied, 212 (68.7\%) had attained menarche, while $99(31.83 \%)$ had not.

The distribution by age at menarche for frequency and mean menarcheal age is shown in Table 1. Majority of the participants 177 (56.91\%) came within the menarcheal age range of 12 - 14 years with mean menarcheal age of $12.90 \pm 0.78$, followed by those of 10 and 11 years menarcheal age with mean of $10.65 \pm 0.64$, $23(7.39 \%)$; and those of $15-17$ menarcheal age with mean of $15.33 \pm 0.65-12$ (3.85\%). The difference between the mean menarcheal ages was statistically significant $(\mathrm{p}=0.000)$.

Table 2 shows the distribution by age at menarche for anthropometric measurements and BMI. The earliest age at menarche was 9 years, and the latest was 17 years. Anthropometric measurements (height and weight) and BMI were significantly higher in the postmenarcheal participants compared to their premenarcheal counterparts $(\mathrm{P}<0.001)$. Anthropometric Measurements and BMI also decreased with increasing age at menarche.

The distribution by nutritional status (range of BMI) for mean menarcheal age as shown in Table 3 indicates that mean menarcheal age was highest (13.10 \pm 1.18 ) for underweight $\left(\mathrm{BMI} \leq 18.5 \mathrm{~kg} / \mathrm{m}^{2}\right.$; lower $(12.76 \pm 1.19)$ for normal (BMI $18.5-24.9 \mathrm{~kg} / \mathrm{m}^{2}$ ), reducing further to $12.70 \pm 1.26$ for overweight (BMI $\left.25.0-29.9 \mathrm{~kg} / \mathrm{m}^{2}\right)$; and lowest $(12.25 \pm 1.25)$ for obese (BMI $30.0-34.9 \mathrm{~kg} / \mathrm{m}^{2}$ ).

Table 1. Distribution by age at menarche for frequency and mean menarcheal.

\begin{tabular}{ccccccc}
\hline Ages at Menarche & $\begin{array}{c}\text { Frequency } \\
(\%)\end{array}$ & $\begin{array}{c}\text { Menarche } \\
\text { Mean } \pm \text { Std }\end{array}$ & Minimum & Maximum & f-value & p-value \\
\hline $10-11$ & $23(7.39)$ & $10.65 \pm 0.64$ & 10.00 & 11.00 & & \\
$12-14$ & $177(56.91)$ & $12.90 \pm 0.78$ & 12.00 & 14.00 & 159.465 & 0.000 \\
$15-17$ & $12(3.85)$ & $15.33 \pm 0.65$ & 15.00 & 17.00 & & \\
$\begin{array}{c}\text { Overall mean age at } \\
\text { menarche }\end{array}$ & $212(68.17)$ & $12.79 \pm 1.20$ & 9.00 & 17.00 & \\
\hline
\end{tabular}


Table 2. Distribution by age at menarche for anthropometric measurements and BMI.

\begin{tabular}{|c|c|c|c|c|c|c|}
\hline $\begin{array}{c}\text { Age } \\
\text { At Menarche }\end{array}$ & Freq (\%) & $\begin{array}{c}\text { HEIGHT } \\
\text { Mean } \pm \operatorname{Std}(M)\end{array}$ & Min & $\operatorname{Max}$ & f-value & p-value \\
\hline NOT YET & $99(31.83)$ & $1.53 \pm 0.08$ & 1.30 & 1.96 & & \\
\hline $9-11$ (Yrs) & $23(7.39)$ & $1.61 \pm 0.07$ & 1.50 & 1.76 & & \\
\hline $12-14$ (Yrs) & $177(56.91)$ & $1.60 \pm 0.07$ & 1.44 & 1.87 & 20.062 & 0.000 \\
\hline $15-17$ (Yrs) & $12(3.86)$ & $1.57 \pm 0.05$ & 1.50 & 1.67 & & \\
\hline Total & $311(100)$ & $1.58 \pm 0.08$ & 1.30 & 1.96 & & \\
\hline $\begin{array}{c}\text { Age } \\
\text { At Menarche }\end{array}$ & Freq (\%) & $\begin{array}{c}\text { WEIGHT } \\
\text { Mean } \pm \text { Std }(\mathrm{Kg})\end{array}$ & Min & $\operatorname{Max}$ & f-value & p-value \\
\hline NOT YET & $99(31.83)$ & $42.51 \pm 6.84$ & 29.00 & 60.00 & & \\
\hline $9-11$ & $23(7.39)$ & $57.45 \pm 9.87$ & 40.00 & 80.00 & & \\
\hline $12-14$ & $177(56.91)$ & $56.16 \pm 8.44$ & 36.00 & 79.00 & 63.011 & 0.000 \\
\hline $15-17$ & $12(3.86)$ & $53.00 \pm 10.83$ & 42.00 & 77.00 & & \\
\hline Total & $311(100)$ & $51.79 \pm 10.35$ & 29.00 & 80.00 & & \\
\hline $\begin{array}{c}\text { Age } \\
\text { At Menarche }\end{array}$ & Freq (\%) & $\begin{array}{c}\text { BMI } \\
\text { Mean } \pm \text { Std }\left(\mathrm{kg} / \mathrm{H}^{2}\right)\end{array}$ & Min & $\operatorname{Max}$ & f-value & $\mathrm{p}$-value \\
\hline NOT YET & $99(31.83)$ & $18.49 \pm 2.78$ & 11.90 & 26.70 & & \\
\hline $9-11$ & $23(7.39)$ & $22.06 \pm 3.41$ & 16.70 & 32.50 & & \\
\hline $12-14$ & $177(56.91)$ & $21.85 \pm 3.14$ & 16.00 & 37.00 & 26.532 & 0.000 \\
\hline $15-17$ & $12(3.86)$ & $21.19 \pm 4.00$ & 16.70 & 29.00 & & \\
\hline Total & $311(100)$ & $20.77 \pm 3.45$ & 11.90 & 37.00 & & \\
\hline
\end{tabular}

Table 3. Distribution by nutritional status (range of BMI) for mean menarcheal age.

\begin{tabular}{|c|c|c|c|c|c|c|}
\hline BMI Classification & Freq (\%) & $\begin{array}{c}\text { Menarche } \\
\text { Mean } \pm \text { Std (Yrs) }\end{array}$ & Min & $\operatorname{Max}$ & f-value & $\mathrm{p}$-value \\
\hline Underweight $\left(18.5\left(\mathrm{~kg} / \mathrm{m}^{2}\right)\right.$ & $30(9.64)$ & $13.10 \pm 1.18$ & 11.00 & 15.00 & & \\
\hline Normal $\left(18.5-24.9 \mathrm{~kg} / \mathrm{m}^{2}\right)$ & $151(48.55)$ & $12.76 \pm 1.19$ & 9.00 & 17.00 & & \\
\hline Overweight $\left(25.0-29.9 \mathrm{~kg} / \mathrm{m}^{2}\right)$ & $27(8.68)$ & $12.70 \pm 1.26$ & 10.00 & 16.00 & 0.990 & 0.399 \\
\hline Obesity $\left(30.0-34.9 \mathrm{~kg} / \mathrm{m}^{2}\right)$ & $4(1.29)$ & $12.25 \pm 1.25$ & 11.00 & 14.00 & & \\
\hline Total & $212(68.17)$ & $12.79 \pm 1.20$ & 9.00 & 17.00 & & \\
\hline
\end{tabular}

Table 4 shows the distribution by the social class of the parents for age at menarche. Although age at menarche increased with reducing social class of $12.56 \pm 1.51 ; 12.76 \pm 1.21$; and $12.90 \pm 1.05$ for high class, middle class, and low class respectively, the difference was not statistically significant $(\mathrm{p}=0.283)$.

The Distribution by category of students (boarding vs. day) for mean menarcheal age as shown in Table 5 indicates that mean menarcheal age was significantly higher for the day students $(12.86 \pm 1.15)$ compared to the boarding students $(12.69 \pm 1.26)(\mathrm{p}<0.001)$. 
Table 4. Distribution by the social class of the parents for age at menarche.

\begin{tabular}{ccccccc}
\hline Social Class & Freq (\%) & $\begin{array}{c}\text { Menarche } \\
(\text { Mean } \pm \text { Std) }(\text { Yrs })\end{array}$ & Minimum & Maximum & f-value & p-value \\
\hline High Class & $41(13.18)$ & $12.56 \pm 1.51$ & 9.00 & 16.00 & & \\
Middle Class & $63(20.26)$ & $12.76 \pm 1.21$ & 11.00 & 17.00 & 1.270 & 0.283 \\
Low Class & $108(34.73)$ & $12.90 \pm 1.05$ & 10.00 & 16.00 & & \\
Total & $211(68.16)$ & $12.79 \pm 1.20$ & 9.00 & 17.00 & & \\
\hline
\end{tabular}

Table 5. Distribution by category of students (boarding vs day) for mean menarcheal age.

\begin{tabular}{ccccccc}
\hline $\begin{array}{c}\text { category of } \\
\text { students }\end{array}$ & Freq (\%) & $\begin{array}{c}\text { Menarche } \\
(\text { Mean } \pm \text { Std) }(\text { Yrs })\end{array}$ & Minimum & Maximum & t-value & p-value \\
\hline Boarding school & $89(28.62)$ & $12.69 \pm 1.26$ & 9.00 & 16.00 & & \\
Day school & $123(39.55)$ & $12.86 \pm 1.15$ & 10.00 & 17.00 & 5.270 & 0.000 \\
Total & $212(68.17)$ & $12.79 \pm 1.20$ & 9.00 & 17.00 & & \\
\hline
\end{tabular}

\section{Discussion}

The mean menarcheal age of the students in this study is $12.79 \pm 1.20$ years. This is similar to menarcheal ages of 13.43 and $12.3 \pm 1.18$ years reported respectively by Okagua et al. [8] in Port-Harcourt and Osemwenkha et al. [9] in Benin City both in south-southern Nigeria. Similar observation has also been reported for different parts of Nigeria [10] [11] and also by Gumanga et al. [21] (12.50 \pm 1.28) in Accra Ghana and Chumlea et al. (12.06 - $12.16 \mathrm{yrs)}$ in USA [26]. The menarcheal age observed in this study is however lower than 15.26 years reported by Tunau et al. [12] from Sokoto, Northwestern Nigeria. It is similarly lower than 15 years reported by Umeora et al. [27] from Abakiliki, Southeastern Nigeria the same area as the present study. This apparent disparity in menarcheal age observed from studies carried out among the women from the same ethnic group as exemplified in our present study, and Umeora et al.'s study is not clear, however, it is pertinent to note that Umeora et al.'s study was conducted 12 years ago amongst rural women of reproductive age between 15 and 49 years many of whom may not accurately recall their ages at menarche, in contradiction to the present study which has been conducted only recently, and amongst adolescent girls (10 - 19 years) with a higher likelihood of a more accurate recollection of their age at menarche.

The mean weight at menarche of the adolescents in this study, $51.79 \pm 10.35$ $\mathrm{kg}$, compares favorably with the mean weight of $53.85 \pm 8.32 \mathrm{~kg}$ reported by Okagua et al. [8] in port-Harcourt amongst their adolescents, with menarcheal age similar to the observation in this study $12.45 \pm 1.24$ and $12.79 \pm 1.20$ years respectively. In contradiction however to the report from Tunau et al. [12] in Sokoto, Nigeria, the mean weight of the adolescents was $48.12 \pm 85 \mathrm{~kg}$ with mean menarcheal age of 15.26 years. This observation implies that lower menarcheal ages are associated with higher weights, thereby assigning a nutritional 
role to age at menarche [10]. This study shows that post-menarcheal girls were taller, and weighed more than the pre-menarcheal girls and this is similar to reports from previous studies [28] [29] [30].

Increasing BMI was also associated with lowering the menarcheal age, and this also agrees with reports from various studies [27] [28] [31]. BMI is a measure of nutritional status. The pre-menarcheal girls in this study have lower BMI $\left(18.49 \pm 2.78 \mathrm{~kg} / \mathrm{m}^{2}\right)$ bothering on underweight compared to the postmenarcheal girls with BMI of $21.7 \pm 3.78 \mathrm{~kg} / \mathrm{m}^{2}$ which fall within normal weight limits. The place of nutritional status as a determinant of menarcheal age therefore becomes readily evident from this observation.

In this study, although no statistically significant difference occurred for menarcheal age for the various social classes, adolescents with parents of high social class had lower mean age at menarche of $12.56 \pm 1.5$ compared to those of middle and low social class with mean menarcheal age of $12.76 \pm 1.2$ and $12.90 \pm 1.9$ respectively. A Polish study conducted during the Soviet Union era had similarly reported a linkage between high social status and early menarche and low socioeconomic class and late menarche [29]. Adolescents with parents of high social class are more likely to be of better nutritional status than those with parents of low social class. In contrast to the above observation, however, Braithwaite et al. [32] had reported that white girls of high social class were protected from early menarche while black girls, irrespective of their social class were not. This suggests that other factors such as race, stress, and environment may be playing a role in the age at menarche.

This study shows that the age at menarche was lower in the boarding-school girls than that of the day-school students. In Nigeria, being a boarding-school student is more expensive to the parents or guardian than being a day student-this indirectly points at the social class of the parents. The disparity in menarcheal age between the boarding and day students may therefore not be unrelated to the likelihood of boarding-school girls being of parents of high social class compared to the day-students whose parents are likely to be of lower social class. In addition, the likelihood of more stress usually experienced by the boarding-school students compared to the day students may constitute a trigger to earlier menarche amongst them [33].

This study has some limitations. The sample size was small and also a schoolbased study. The finding of this study may not be appropriate for generalization as out-of-school adolescent girls were not included in the study. A more encompassing study involving all the segments of adolescent girls vis-à-vis in-school and out-of-school girls is recommended.

\section{Conclusion}

This study shows that the mean age at menarche amongst the adolescent secondary school girls was $12.79 \pm 1.2$ years. There was a significant relationship between age at menarche and the nutritional status of the participants. Students 
with parents of high social class and those in boarding houses had a relatively lower age at menarche. Adequate attention should be given to the nutrition of premenarcheal school girls and those of parents with low social class. Boarding school authorities should ensure measures to alleviate stress amongst boarding-school students.

\section{Conflicts of Interest}

The authors declare no conflicts of interest regarding the publication of this paper.

\section{References}

[1] Jenkins, R.R. (2008) The Epidemiology of Adolescent Disease. In: Behram, R.E., Kliegman, R.M. and Jenson, H.B., Eds., Nelson Textbook of Paediatrices, 18th Edition, WB Saunders Company, Philadelphia, 836.

[2] Gaudineau, A. (2010) Factors Associated with Early Menarche: Result from French Health Behaviour in School Aged Children (HBSC) Study. BMC Public Health, 10, Article No. 175. https://doi.org/10.1186/1471-2458-10-175

[3] Mounir, G.H., El-Sayed, N.A., Mahdy, N.H. and Khamis, S.E. (2007) Nutritional Factors Affecting the Menarcheal State of Adolescent Girls in Alexandria. Journal of the Egyptian Public Health Association, 82, 239-260.

[4] Laitinen, J., Power, C. and Jarvelin, M.R. (2001) Family, Social Class, Maternal Body Mass Index, Childhood Body Mass Index and Age at Menarche as Predictors of Adult Obesity. The American Journal of Clinical Nutrition, 74, 287-294. https://doi.org/10.1093/ajcn/74.3.287

[5] Proverawanti, A. and Misaroh, S. (2009) Menarche. Nuhumedika, Yogyakarta, 1-74.

[6] Wahab, A., Wilopo, S., Hakimi, M. and Ismail, D. (2020) Declining Age at Menarche in Indonesia: A Systematic Review and Meta-Analysis. International Journal of Adolescent Medicine and Health, 32.

[7] Canelo, S.P. and Boland, M.R. (2020) A Systematic Review of Factors Affecting the Timing of Menarche: The Potential for Climate Change to Impact Women's Health. International Journal of Environmental Research and Public Health, 17, Article No. 1703. https://doi.org/10.3390/ijerph17051703

[8] Okagua, J. and Okagua, K.E. (2015) Menarcheal Age and Nutritional Status among School Girls in Port Harcourt, Southern Nigeria. Tropical Journal of Obstetrics and Gynaecology, 32, 145-151.

[9] Osemwenkha, A.P., Osaikhuwuomwan, J.A. and Chukwudi, E.O. (2014) Age at Menarche among Secondary School Girls in an Urban Population of Nigeria. Nigerian Journal of Experimental and Clinical Biosciences, 2, 95-99. https://doi.org/10.4103/2348-0149.144844

[10] Onyiriuka, A.N. and Egbagbe, E.E. (2013) Anthropometry and Menarcheal Status of Adolescent Nigerian Urban Senior Secondary School Girls. International Journal of Endocrinology and Metabolism, 11, 71-75. https://doi.org/10.5812/ijem.8052

[11] Abioye-Kuteyi, E.A., Ojofeitimi, E.O., Aina, O.I., Kio, F., Aluko, Y. and Mosouro, O. (1997) The Influence of Socio-Economic and Nutritional Status on Menarche in Nigerian School Girls. Nutrition and Health, 11, 185-195. https://doi.org/10.1177/026010609701100304

[12] Tunau, K.A., Adamu, A.N., Hassan, M.A., Ahmed, Y. and Ekele, B.A. (2012) Age at 
Menarche among School Girls in Sokoto, Northern Nigeria. Annals of African Medicine, 11, 103-107. https://doi.org/10.4103/1596-3519.93533

[13] Adesina, A.F. and Peterside, O. (2013) Age of Menarche and Body Mass Index among Adolesecent Girls in Portharcoourt, Nigeria. Journal of Defense Modeling and Simulation, 3, 41-46.

[14] Adinma, J.I.B. (2018) Adolescent, Pre-Pregnancy and Maternal Nutrition. In: The Total Woman and Her Man: Diseases, Disorders, and Other Conditions Peculiar to Women, Mindex Pubihing Company Ltd., Lagos, 81-96.

[15] Adinma, J.I., Umeononihu, O.S. and Umeh, M.N. (2017) Maternal Nutrition in Nigeria. Tropical Journal of Obstetrics and Gynaecology, 34, 79-84. https://doi.org/10.4103/TJOG.TJOG_25_17

[16] Adinma, J.I., Umeononihu, O.S. and Umeh, M.N. (2017) Adolescent and PrePregnancy Nutrition in Nigeria. Tropical Journal of Obstetrics and Gynaecology, 34, 1-5. https://doi.org/10.4103/TJOG.TJOG_12_17

[17] Adinma, J., Adinma, E. and Umeononihu, O. (2017) Nutrition Policy and Practice Landscape on Adolescent, Pre Pregnancy and Maternal Nutrition in Nigeria. JOJ Nursing \& Health Care, 1, Article ID: 555560. https://doi.org/10.19080/JOJNHC.2017.01.555560

[18] Adinma, J.I.B., Oguaka, V.N., Okafor, C.I., Udigwe, G.O., Adinma Obiajulu, N.D. and Edet, M.M. (2019) Serum Calcium Levels, Uterine Contractility and Labour in Parturient Nigerian Igbo Women. British Journal of Biomedical Research, 3, 1085-1093.

[19] Adinma, J.I.B., Nwankwo, M.C., Ahaneku, J.E., Ugboaja, J.O., Ibe, C.C., Edet, M.M. and Vitamin, D. (2019) Status of Pregnant Women and the Association between Vitamin D Levels and Selected Pregnancy Outcomes. International Journal of Science and Research, 8, 1568-1571.

https://www.ijsr.net/search_index_results_paperid.php?id=ART2020146

[20] Adinma, J.I.B., Ahaneku, J.E., Adinma, E.D., Ugboaja, J.O., Egeonu, R.O., Edet, M.M. (2020) Vitamin D Status and Its Influence on Pregnancy Outcomes Amongst Pregnant Women in Southeastern Nigeria. World Journal of Advanced Research and Reviews, 7, 89-98. https://doi.org/10.30574/wjarr.2020.7.2.0264

[21] Gumanga, S.K. and kwame-Aryee, R.A. (2012) Menstrual Characteristics in Some Adolescent Girls in Accra, Ghana. Ghana Medical Journal, 46, 3-7.

[22] Federal Republic of Nigeria Official Gazette (2007) Legal Notice on Publication Details of the Breakdown of the National and State Provisional Totals 2006 Census.

[23] World Health Organization (1995) Physical Status: The Use and Interpretation of Anthropometry. Technical Report Series No. 854, World Health Organization, Geneva.

[24] Cole, T.J. (1997) Sampling Study Size and Power. In: Margrets, B.M. and Nelson, M., Eds., Design Concept of Nutritionally Epidemiology, Oxford University Press, New York, 64-86. https://doi.org/10.1093/acprof:oso/9780192627391.003.0003

[25] World Health Organization (2007) BMI-for-Age Table. http://www.who.int/growthref/who2007

[26] Chumlea, W.C., Schubert, C.M., Roche, A.F., Kulin, H.E., Lee, P.A., Himes, J.H., et al. (2003) Age at Menarche and Racial Comparisons in United States Girls. Pediatrics, 111, 110-113. https://doi.org/10.1542/peds.111.1.110

[27] Umeora, O.U.J. and Egwuatu, V.E. (2008) Age at Menarche and the Menstrual Pattern of Igbo Women of Southeast Nigeria. African Journal of Reproductive Health, 12, 90-91. 
[28] Goon, D.T., Toriola, A.L., Uever, J., Wuam, S. and Toriola, O.M. (2010) Growth Status and Menarcheal Age among Adolescent School Girls in Wannune Benue state, Nigria. BMC Pediatrics, 10, Article No. 60.

https://doi.org/10.1186/1471-2431-10-60

[29] Raji, Y., Osunuga, O.A., Shittu, O.S., Akinsomisoye, V.A., Togun, V.A. and Azeeez, M. (2006) Age at Menarche and Its Predicting Factors in Cities of Ibadan and Ogbomosho of Southwestern Nigeria. Journal of Medical Sciences, 6, 772-778. https://doi.org/10.3923/jms.2006.772.778

[30] Bagga, A. and Kulkarni, S. (2000) Age at Menarche and Secular Trend in Maharashtrian (India) Girls. Acta Biologica Szeged, 44, 53-57

[31] Bielick, T. and Welon, Z. (1982) Growth Data as Indicator of Social Inequalities: The Case of Poland. American Journal of Physical Anthropology, 25, 153-167. https://doi.org/10.1002/ajpa.1330250509

[32] Braithwaite, D., Moore, D.H., Lustig, R.H., Epel, E.S., Ong, K.K., Rehkopf, D.H., et al. (2009) Socioeconomic Status in Relation to Early Menarche among Black Girls and While Girls. Cancer Causes \& Control, 20, 713-720. https://doi.org/10.1007/s10552-008-9284-9

[33] Campbell, B.C. and Udry, J.R. (1995) Stress and Age at Menarche of Mothers and Daughters. Journal of Biosocial Science, 27, 127-134.

https://doi.org/10.1017/S0021932000022641 